\title{
TERAPI RELAKSASI OTOT PROGRESIF DAN RENDAM KAKI DENGAN AIR HANGAT TERHADAPAT SKALA INSOMNIA PADA LANSIA DI PANTI TRESNA WERDHA KARITAS CIMAHI
}

\author{
THERAPY RELAXATION OF PROGRESSIVE MUSCLE AND SOAKING FEET WITH \\ WARM WATER THROUGH INSOMNIA SCALE FOR THE ELDERLY IN PANTI \\ TRESNA WERDHA KARITAS CIMAHI
}

\author{
Coraldo Sadrak Mekel Dondok ${ }^{1}$, Nilawati Soputri Sulaiman² \\ Fakultas Ilmu Keperawatan, Universitas Advent Indonesia \\ E-Mail: Coraldo56@gmail.com
}

\begin{abstract}
ABSTRAK
Pendahuluan: Insomnia pada orang lanjut usia (lansia) dapat diatasi dengan menggunakan beberapa cara, diantaranya dengan melakukan terapi relaksasi otot progresif dan rendam kaki dengan air hangat, namun diantara keduanya belum diketahui mana yang lebih efektif dalam menurunkan insomnia pada lansia. Tujuan: Penelitian ini bertujuan untuk membandingkan efektifitas antara terapi relaksasi otot progresif dan rendam kaki dengan air hangat dalam mengatasi insomnia lansia di Panti Werdha Karitas Cimahi. Metode: Metode penelitian yang digunakan adalah Quasi experimental dengan desain pre-test and post-test. Subjek dalam penelitian ini sebanyak 17 orang lansia yang diberikan dua intervensi pada waktu yang berbeda. Sebelum diberi intervensi skala insomnia subjek diukur dengan menggunakan kuesioner insomnia rating scale (IRS). Intervensi pertama adalah pemberian terapi relaksasi otot progresif selama tiga kali dalam seminggu, lalu diukur kembali skala insomnia subjek pada hari terkahir pada minggu tersebut dengan menggunakan insomnia rating scale (IRS). Setelah itu subjek diistirahatkan selama satu minggu. Sesudah itu dilanjutkan dengan pemberian intervensi kedua yaitu rendam kaki dengan air hangat selama tiga kali dalam seminggu dan pada hari terakhir skala insomnia subjek diukur kembali dengan menggunakan kuesioner insomnia rating scale (IRS)). Hasil: Skala insomnia sebelum terapi relaksasi otot progresif dan rendam kaki dengan air hangat adalah 11.71. Skala insomnia sesudah Terapi relaksasi otot progresif adalah 9.00 dan hasil sesudah rendam kaki dengan air hangat adalah 8.88. Diskusi: Tidak ada perbedaan yang signifikan terhadap skala insomnia antara terapi relaksasi otot progresif dan rendam kaki dengan air hangat pada lansia di Panti Tresna Werdha Karitas Cimahi.
\end{abstract}

Kata Kunci: Insomnia, Relaksasi Otot Progresif, Rendam Kaki dengan Air Hangat

\section{ABSTRACT}

Introduction: Insomnia in elderly can be somehow managed in several ways, such as by doing progressive muscle relaxation therapy and soaking feet in warm water, but between them not yet known which is more effective in lowering insomnia for elderly. Purpose: to find out which is more effective between progressive muscle relaxation therapy and soaking feet in warm water to the scale of elderly insomnia in Pati Werdha Karitas Cimahi. Method: The experimental method for this study is experimental quasi with pre-test and post-test non-Random. The Subjects in this study were 17 elderly people who were given two interventions at different times. Before being given insomnia scale intervention the subject was measured using a rating scale insomnia (IRS) questionnaire. The first intervention was the provision of progressive muscle relaxation for three times a week, then measured Returns the subject's insomnia scale on the last day of the week using an insomnia rating scale (IRS). After that the subject is rested for one week. Subsequently, a second intervention was performed, soaking the feet with warm water for three times a week and on the last day the subject's insomnia scale was re-measured using an Insomnia rating scale (IRS). Result: Insomnia scale before progressive muscle relaxation therapy and soaking feet with the

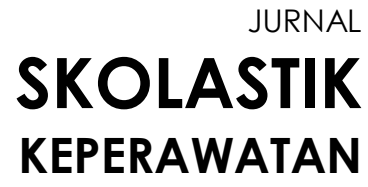

Vol, 3, No. 2

Juli - Desember 2017

ISSN: $2443-0935$

E-ISSN 2443 - 1699 
warm water is 11.71. The insomnia scale after progressive muscle relaxation therapy is 9.00 and the result after soaking the foot with warm water is 8.88. Discussion: There is no significant difference to the insomnia scale for the elderly, between progressive muscle relaxation therapy and soaking feet with warm water at Panti Tresna Werdha Karitas Cimahi.

Key words: Insomnia, Muscle Relaxation Progressive, Soaking Feet with Warm Water

\section{PENDAHULUAN}

Tidur ialah salah satu aspek yang bermanfaat bagi kesehatan lansia. Tidur yang cukup diyakini dapat mengoptimalkan kesehatan tubuh, karena tidur bermanfaat untuk menyimpan energi, meningkatkan imunitas tubuh dan mempercepat proses penyembuhan penyakit. Namun, $50 \%$ lansia yang tinggal di rumah dan $66 \%$ yang tinggal di panti werdha mengalami penurunan kualitas tidur pada malam hari (Adiyanti, 2010).

Nurhalim (2013) menyatakan, Indonesia termasuk lima besar negara dengan jumlah penduduk lansia terbesar di dunia yakni 18,1 juta jiwa atau 9,6 persen dari jumlah penduduk. Menurut Effendi (2016) jika dibandingkan dengan data yang ada pada tahun 1970, jumlah penduduk Indonesia yang berusia diatas 70 kurang dari dua juta jiwa, namun pada tahun 2015 jumlah ini meningkat karena ada kenaikan sebayak 15 kali lipat yakni mendekati angka 30 juta jiwa. Hal tersebut dapat berdampak positif jika lansia dalam kedaan sehat, tetapi jika dalam keadaan kurang sehat maka potensi kerugian negara dari pembiyaan Jaminan Kesehatan Nasional (JKN) akan meningkat (Sulaiman, 2016). Menurut Rahman (2014) dampak insomnia dapat diatasi dengan manggunakan pendekatan farmakologi atau non farmakologi. Terapi farmakologi memiliki efek yang cepat.
Namun, menurut (Larayanthi, 2013) penggunaan obat-obatan golongan sedatif dalam jangka waktu yang panjang dapat berbahaya bagi kesehatan lansia. Sedangkan terapi nonfarmakologi diketahui memiliki efek samping yang minim namun efektif. Salah satu pengobatan secara non farmakologis dalam mengatasi gangguan tidur adalah teknik relaksasi otot progresif (Setyoadi, Lestari dan \& Kusuma, 2016)

Nuryanti (2014) menyatakan, dalam buku progressive Relaxation yang diperkenalkan oleh Jacob (1950) bahwa latihan relaksasi otot progresif merupakan kombinasi latihan pernafasan dan rangkaian kontraksi serta relaksasi kelompok otot. Latihan relaksasi progresif yang dilaksanakan 15-20 menit, satu kali sehari secara teratur selama satu minggu cukup efektif dalam menurunkan insomnia. Metode non farmakologi lainnya yang dapat meningkatkan kualitas tidur ialah teknik merendam kaki pada air hangat. Menurut Utami (2015) dengan merendam kaki pada air hangat bersuhu $37^{\circ} \mathrm{C}-39^{\circ} \mathrm{C}$ dapat meningkatkan kualitas tidur lansia. Berdasarkan penelitian yang telah dijelaskan diatas terbukti bahwa terapi relaksasi otot progresif dan rendam kaki pada air hangat efektif dalam menurunkan insomnia pada lansia, tetapi diantara keduanya belum diketahui mana yang lebih efektif dalam menurunkan insomnia. Disamping itu studi 
kepustakaan yang telah peneliti lakukan belum ada yang pernah meneliti tentang perbandingan efektifitas antara terapi relaksasi otot progresif dan rendam air hangat. Sebab itu peneliti ingin melakukan penelitian tentang: Efektivitas Terapi Relaksasi Otot Progresif Dan Rendam Kaki Dengan Air Hangat Terhadap Skala Insomnia Pada Lansia di Panti Tresna Werdha Karitas Cimahi.

\section{TUJUAN PENELITIAN}

Tujuan dari penelitian yang dilakukan adalah untuk:

1. Mengidentifikasi skala insomnia sebelum terapi kepada kelompok.

2. Mengidentifikasi skala insomnia sesudah pemberian terapi relaksasi otot progresif.

3. Mengidentifikasi skala insomnia sesudah pemberian rendam kaki dengan air hangat.

4. Menganalisis perbedaan relaksasi otot progresif dan rendam kaki dengan air hangat dalam menurunkan insomnia pada lansia di Panti Tresna Werdha Cimahi.

\section{MANFAAT PENELITIAN}

Hasil yang dilakukan diharapkan berguna bagi:

1. Kepala Panti Tresna Werdha sebagai bahan masukan untuk membantu lansia dalam mengatasi insomnia.

2. Bidang Keperawatan, sebagai bahan masukan dalam memberi intervensi keperawatan pada lansia dengan insomnia.

3. Bidang penelitian sebagai bahan acuan serta pengembangan lanjutan untuk penelitian selanjutnya.

\section{BAHAN DAN METODE}

Metode yang digunakan dalam penelitian ini adalah Quasi Experimental dengan desain pre-test dan post-test.

Populasi yang diteliti dalam penelitian yang dilakukan adalah lansia di panti Tresna werdha Cimahi. Sampel penelitian ini adalah 17 orang lansia yang mengalami insomnia yang dipilih dengan cara purposive sampling.

Adapun pemilihan sampel dilakukan berdasarkan beberapa kriteria inklusi yaitu:

1. Subjek penelitian merupakan lansia perempuan yang tinggal di panti werdha Tresna Werdha Karitas Cimahi yang mengalami insomnia.

2. Subjek berusia 60-74 tahun (elderly)

3. Subjek yang diteliti tidak mengkonsumsi obat sedatif seperti benzodiazepine, nonbenzodiazepine, eszoplicone, ramelteon, herbal.

4. Subjek yang diteliti tidak memakan/meminum yang mengandung kafein (kopi).

5. Subjek dapat bermobilisasi, tidak memiliki respiratory problem (sesak) dan endocrine problem.

6. Subjek penelitian secara sukarela ikut berpartisipasi dalam penelitian yang akan dilakukan.

\section{HASIL PENELITIAN}

Pengolahan data dilakukan setelah data based insomnia didapatkan. Data diolah guna memberikan jawaban untuk mengidentifikasi masalah pertama sampai keempat. Dari hasil tersebut dilakukan pengolahan data untuk menjawab identifikasi masalah pertama sampai ketiga dengan Wilcocoxon Signed-Rank 
Test. Identifikasi masalah keempat di analisis menggunakan rumus paired t-test. Namun, jika data tidak berdistribusi dengan normal maka akan dilakukan uji Mann-Whitney.

\section{Identifikasi Masalah Pertama: "Bagaimanakah Skala Insomnia Sebelum Dilakukan Eksperimen Pada Kelompok?"}

\section{Menjawab identifikasi masalah pertama, yaitu: "Skala insomnia sebelum dilakukan eksperimen pada kelompok?" maka dihitung mean skala insomnia dengan menggunakan SPSS metode Wilcoxon Rank. dapat diketahui bahwa semua responden yang merupakan lansia mengalami insomnia. Nilai kuesioner terendah adalah 7 dan tertinggi adalah 14. Adapun rata-rata nilai dari keseluruhan responden adalah sebelum adalah 11.71 berada pada kategori insomnia ringan. \\ 2. "Bagaimanakah Skala Insomnia Sesudah Terapi Relaksasi Otot Progresif Pada Lansia?}

Menjawab identifikasi masalah kedua, yaitu: Bagaimanakah skala insomnia sesudah terapi relaksasi otot progresif pada lansia? maka dihitung mean skala insomnia dengan menggunakan SPSS metode Wilcoxon Signed-Rank. Berdasarkan analisa dengan menggunakan Wilcoxon Signed-Rank Test maka didapatkan hasil bahwa nilai rata-rata lansia setelah mengikuti terapi berelaksasi otot progresif mengalami penurunan menjadi 9.00 yang tergolong kedalam insomnia ringan. Berdasarkan hasil dari perhitungan Wilcoxon Signed-Rank Test, maka nilai $\mathrm{Z}$ yang didapat sebesar -3.669 dengan $p$ value (Asymp. Sig 2 tailed) sebesar 0,00 di mana kurang dari batas kritis penelitian 0,05 sehingga keputusan hipotesis adalah menerima $\mathrm{H}_{0} 3$ atau yang berarti terdapat perbedaan bermakna antara kelompok pre-test dan post-test.

\section{3. "Bagaimanakah Skala Insomnia Sesudah Rendam Kaki Dengan Air Hangat Pada Lansia?"}

Menjawab identifikasi masalah kedua, yaitu:

Bagaimanakan skala insomnia sesudah rendam kaki dengan air hangat pada lansia? maka dihitung mean skala insomnia dengan menggunakan SPSS metode Wilcoxon Signed-Rank Test. Berdasarkan analisa diatas maka nilai rata-rata lansia yang mengalami insomnia sesudah diberikan terapi rendam kaki dengan air hangat adalah 8.88 yang tergolong dalam skala insomnia ringan. Berdasarkan hasil dari perhitungan Wilcoxon Signed Rank Test, maka nilai $\mathrm{Z}$ yang didapat sebesar 3.677 dengan $p$ value (Asymp. Sig 2 tailed) sebesar 0,00 di mana kurang dari batas kritis penelitian 0,05 sehingga keputusan hipotesis adalah menerima $\mathrm{H}_{0} 3$ atau yang berarti terdapat perbedaan bermakna antara kelompok pre-test dan post-test.

\section{4. "Adakah Perbedaan yang Signifikan Antara Terapi Teknik Relaksasi Otot Progresif dan Rendam Kaki dengan Air Hangat Dalam Menurunkan Insomnia pada Lansia?"}

Menjawab identifikasi masalah keempat, yaitu: Adakah Perbedaan yang Signifikan Antara Terapi Teknik Relaksasi Otot Progresif dan Rendam Kaki dengan Air Hangat Dalam Menurunkan Insomnia pada Lansia? Maka dilakukan uji normalitas terlebih dahulu. Menurut 
Dahlan (2013) normalitas dapat dilihat dari perolehan signifikan, apabila sig. $\geq$ 0.05 maka data berdistribusi normal, namun apabila sig. $\leq 0.05$ maka data tidak berdistribusi normal. Data yang dihasilkan pada kedua kelompok eksperimen tidak berdistribusi dengan normal, maka dilakukan uji Mann Whitney.

Tabel 1.

Uji Mann Whitney

Test Statistics $^{\mathrm{a}} \quad$ EXPERIMEN

\begin{tabular}{ll}
\hline Mann-Whitney $U$ & 75.50 \\
Wilcoxon W & 166.50 \\
Z & -.49 \\
Asymp. Sig. $\quad(2-$ & .62 \\
tailed) & \\
Exact Sig. $\quad\left[2^{*}(1-\right.$ & $.65^{\mathrm{b}}$ \\
tailed & \\
Sig.)] & \\
\hline
\end{tabular}

a. Grouping Variable: Bagian

b. Not corrected for ties.

Tabel hasil uji analisa Mann Whitney diatas dapat diketahui bahwa nilai signifikasi adalah 0.623 , lebih besar dari signifikasi 0.05 yang artinya bahwa tidak terdapat perbedaan nilai yang signifikan antara terapi relaksasi otot progresif dengan rendam kaki menggunakan air hangat terhadap skala insomnia pada lansia, maka hipotesis yang mengatakan bahwa tidak ada perbedaan skala insomnia sesudah terapi relaksasi otot progresif dengan terapi rendam kaki menggunakan air hangat, diterima. Perolehan hasil diatas menyatakan bahwa tidak ada perbedaan yang signifikan antara terapi relaksasi otot progresif dengan terapi rendam kaki menggunakan air hangat terhadap skala insomnia lansia di panti Tresna Wredha Karitas Cimahi.

\section{PEMBAHASAN}

\section{Bagaimanakah Skala Insomnia Sebelum Dilakukan Eksperimen}

Berdasarkan analisa di atas dapat disimpulkan bahwa nilai rata-rata adalah 11.71 yang artinya subjek mengalami insomnia dengan kategori ringan. Bebrerapa factor yang memepengaruhi terjadinya insomnia adalah (Larasaty, 2015):

1. Faktor Psikologis

2. Faktor Lingkungan

3. Perubahan Pola Tidur

4. Asupan Nutrisi

5. Ketidak nyamanan fisik

\section{Skala Insomnia Sesudah Terapi Relaksasi Otot Progresif}

Berdasarkan analisa dapat disimpulkan bahwa nilai rata-rata lansia yang mengalami insomnia sesudah diberikan terapi relaksasi otot progresif adalah 9.00 yang artinya insomnia yang dialami subjek mengalami penurunan. Serupa dengan hasil penelitian dari Yulianan, dkk (2015) yang menunjukkan bahwa subjek yang mengalami insomnia sesudah terapi relaksasi otot progresif mengalami penurunan.

\section{Skala Insomnia Sesudah Rendam Kaki Dengan Air Hangat}

Berdasarkan analisa dapat disimpulkan bahwa nilai rata-rata lansia yang mengalami insomnia sesudah diberikan rendam kaki dengan air hangat adalah 8.88 yang artinya insomnia yang dialami subjek mengalami penurunan. Serupa 
dengan penelitian yang dilakukan oleh Utami (2015) kepada 20 subjek di Panti Sosial Tresna Werdha Yogyakarta Unit Budi Luhur yang menunjukan bahwa adanya pengaruh rendam kaki dengan air hangat dengan hasil signifikansi 0.004 $(\leq 0.005)$.

Hal tersebut terjadi karena terapi rendam kaki dengan air hangat dapat menyebabkan efek sofarik (efek inigin tidur). Efek sofarik terjadi karena didaerah kaki terdapat banyak saraf terutama dikulit yaitu flexus venosus dan dari rangkaian saraf ini stimulasi dari rendam kaki dengan air hangat ditreruskan ke kornu posterior kemudian dilanjutkan ke medulla spinalis, lalu dilanjutkan ke lamina I, II, III radiks dorsalis, selanjutnya ke ventro basal thalamus dan masuk ke batang otak tepatnya di daerah rafe bagian bawah spons dan medulla (Khotimah, 2011).

\section{Perbedaan antara Terapi Teknik Relaksasi Otot Progresif dan Rendam Kaki dengan Air Hangat Dalam Mengatasi Insomnia}

Berdasarkan analisa data, dapat ditarik kesimpulan bahwa tidak ada perbedaan efektifitas yang signifikan pada skala insomnia dismenore setelah terapi relaksasi otot progresif dan rendam kaki dengan air hangat terhadap skala insomnia pada lansia di Panti Tresna Werdha Karitas Cimahi.

Dapat dilihat nilai mean terapi relaksasi otot progresif berada pada nilai 9.00 dan nilai mean dari jalan cepat adalah 8.88. Jumlah nalai mean dari rendam kaki dengan air hangat lebih kecil jika dibandingkan terapi relaksasi otot progresif. Dapat ditarik kesimpulan bahwa rendam kaki dengan air hangat lebih efektif dalam menurunkan skala insomnia dibandingkan dengan terapi relaksasi otot progresif.

Teknik relaksasi otot progresif adalah Teknik relaksasi yang progresif memusatkan perhatian pada suatu aktivitas otot dengan mengidentifikasi otot yang tegang kemudian menurunkan ketegangan dengan melakukan teknik relaksasi untuk mendapatkan perasaan relaks (Niven, 2012). Terapi relaksasi otot progresif bermanfaat untuk menurunkan resistensi perifer dan menaikkan elastisitas pembuluh darah. Otot- otot dan peredaran darah akan lebih sempurna dalam mengambil dan mengedarkan oksigen serta relaksasi otot progresif dapat bersifat vasodilator yang efeknya memperlebar pembuluh darah dan dapat menurunkan tekanan darah secara langsung. Relaksasi otot progresif ini menjadi metode relaksasi termurah, tidak memerlukan imajinasi, tidak ada efek samping, mudah dilakukan, membuat tubuh dan pikiran terasa tenang dan rileks (Maryam, 2010).

\section{KESIMPULAN}

Kesimpulan yang diperoleh dari penelitian yang telah dilakukan dan uji statistik yang digunakan dalam penelitian ini adalah:

1. Skala insomnia sebelum terapi relaksasi otot progresif dan rendam kaki dengan air hangat adalah 11.71 (insomnia sedang).

2. Skala insomnia sesudah terapi relaksasi otot progresif adalah 9.00 (insomnia sedang)

3. Skala insomnia sesudah terapi rendam kaki dengan air hangat adalah 8.88 (insomnia sedang)

4. Tidak ada perbedaan yang signifikan antara terapi relaksasi otot progresif dan rendam kaki dengan air hangat 
terhadap skala insomnia pada lansia di Panti Tresna Werdha Karitas Cimahi.

\section{DAFTAR PUSTAKA}

Adiyati, S. Pengaruh Aromaterapi Terhadap Insomnia pada Lnsia di PSTW Unit Budi Maryam, S. (2010). Buku Panduan Kader Posbindu Lansia. Jakarta Timur: Cv. Trans Info Media.

Dahlan, M. S. (2013). Statistik Untuk Kedokteran dan Kesehatan. Jakarta: Salemba Medika.

Effendi, T. Agustus 6, 2016. http://www.kompasiana.com/t jiptadinataeffendi21may43/ju mlah-lansia-diindonesiameningkat15kali_568bc5ccd57a61d112d00 397 (Diunduh Desember 1, 2016).

Khotimah. (2011). Pengaruh Rendam Air Hangat Pada Kaki Dalam Meningkatan Kuantitas Tidur Lansia. Fakultas Ilmu Kesehatan, Universitas Pesantren Tinggi Darul Ulum Jombang.

Larasati. (2015). Penyebab Insomnia pada Lansia. [Online]. Available.http://health.liputan6.co $\mathrm{m} / \mathrm{rea}$ $\mathrm{d} / 2231643 / 5$ penyebabhttp://health.liputan6.co $\mathrm{m} / \mathrm{read} / 2231643 / 5$-penyebabinsomnia-pada-lansiainsomniapada-lansia. diakses pada 5 April 2017. Larayanthi, C, I, D. "Penatalaksanaan Insomnia pada Pasien Geriatri." 2013. Nuryanti, L. Pengaruh Relaksasi Otot Progresif Terhadap Insomnia Pada Lansia di PSTW Budi Dharma Bekasi, 2014.

Niven, N. (2012). Psikologi

Kesehatan: Pengantar Untuk Perawat Dan Profesional Kesehatan Lain Edisi 2. Jakarta: EGC.

Utami, T. Pengauruh Rendam Air Hangat Pada Kaki Terhadap Insomnia Pada Lansia di Panti Sosial Tresna Werdha Yogyakarta Unit Budi Luhur, 2015.

Setyoadi, \& Kushariyadi. (2011). Terapi Modalitas Keperawatan Jiwa pada Klien Psikogeriatrik. Jakarta: Salemba Medika.

Yulianan, dkk. (2013). Pengaruh Terapi Relaksasi Otot Progresif Terhadap Perubahan Tingkat Insomnia Pada Lansia di Panti Werdha Manado. eJournal Keperawatan (e-Kep) Volume 3. Nomor 1. Maret 2015. Manado: Universitas Sam Ratulangi. 